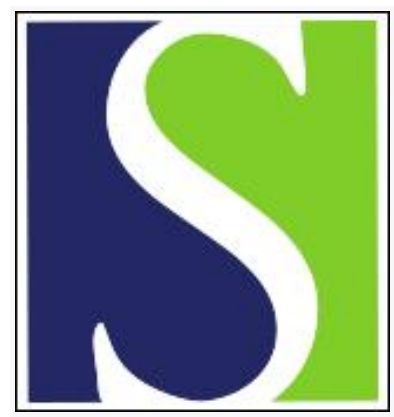

Scand J Work Environ Health 2020;46(2):209-217

https://doi.org/10.5271/sjweh.3853

Published online: 01 Oct 2019, Issue date: 01 Mar 2020

Status incongruence in human service occupations and implications for mild-to-severe depressive symptoms and register-based sickness absence: A prospective cohort study by Nyberg A, Johansson G, Westerlund H, Rostila M, Toivanen S

The study contributes with a completely novel hypothesis, namely that negative status incongruence between educational attainment and subjective social status may partly explain the excess risk of mental ill-health and sickness absence among employees in human service occupations. The results support this hypothesis with possible implications for associations between established work stressors and health.

Affiliation: Anna Nyberg, Stress Research Institute, Stockholm University, 10691 Stockholm, Sweden. anna.nyberg@su.se

Refers to the following texts of the Journal: 2013;39(6):535-549 2006;32(6):443-462

The following article refers to this text: 2022;48(8):632-640

Key terms: cohort study; depression; depressive symptom; gender; gender theory; human service occupation; mental health; mild-to-severe depressive symptom; prospective cohort study; register; register-based sickness absence; sick leave; sickness absence; status incongruence; status inconsistency

This article in PubMed: www.ncbi.nlm.nih.gov/pubmed/31570947

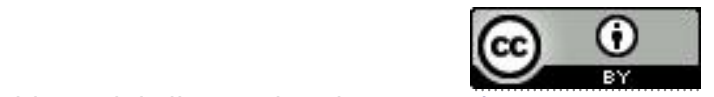




\title{
Status incongruence in human service occupations and implications for mild-to-severe depressive symptoms and register-based sickness absence: A prospective cohort study
}

\author{
by Anna Nyberg, PhD, ${ }^{1}$ Gun Johansson, PhD, ${ }^{2}$ Hugo Westerlund, PhD, ${ }^{1}$ Mikael Rostila, PhD, ${ }^{3}$ Susanna Toivanen, PhD ${ }^{3,4}$
}

\begin{abstract}
Nyberg A, Johansson G, Westerlund H, Rostila M, Toivonen S. Status incongruence in human service occupations and implications for mild-to-severe depressive symptoms and register-based sickness absence: A prospective cohort study. Scand J Work Environ Health. 2020;46(2):209-217. doi:10.5271/sjweh.3853
\end{abstract}

Objective This study aimed to investigate the hypothesis that negative status incongruence may contribute to explain higher risk of mental ill-health and sickness absence in human service occupations (HSO).

Methods Participants from the Swedish Longitudinal Occupational Survey of Health who responded to questionnaires in both 2014 and 2016 (N=11 814; 42\% men, 58\% women) were included. Status incongruence between register-based educational level and subjective social status was assessed. The association between employment in a HSO and status incongruence was estimated in linear regression analyses adjusted for age, income, work hours, sickness absence, childcare, and job qualification match. The prospective associations between status incongruence and mild-to-severe depressive symptoms and register-based sickness absence $\geq 31$ days respectively were estimated with logistic regression analyses in models adjusted for age and outcomes at baseline. All analyses were stratified by gender.

Results Employment in a HSO was associated with more negative status incongruence in both genders [standardized coefficient men $0.04,95 \%$ confidence interval (CI) 0.02-0.07; women 0.06, 95\% CI 0.04-0.09]. More negative status incongruence was furthermore associated with higher odds of mild-to-severe depressive symptoms (men OR 1.18, 95\% CI 1.08-1.29; women OR 1.17, 95\% CI 1.09-1.26) and sickness absence $\geq 31$ days (men OR 1.40, 95\% CI 1.23-1.59; women OR 1.17, 95\% CI 1.07-1.28) two years later.

Conclusion Status incongruence is somewhat higher among HSO than other occupations and associated with increased odds of depressive symptoms and sickness absence.

Key terms depression; gender; gender theory; mental health; sick leave; status inconsistency.

A large number of the Swedish workforce, particularly women, are employed in occupations in which contact with children, students, sick, or older people is part of the everyday work tasks (1). It has in recent years been acknowledged that employees in these so-called "human service occupations" (HSO) have increased risks of mental ill-health and sickness absence compared with other occupations on the Swedish labor market $(1,2)$. Several possible reasons for this increase have been suggested, such as poorer working conditions in these professions (2) and a higher total burden of emotionally demanding work from paid and unpaid work together (3). However, the increased risks may also be due to a negative incongruence between the high education required for many of these professions and the perceived social status associated with them. According to gender theory $(4,5)$, different job tasks are assigned gendered symbolic meanings and status. Technical work tasks are typically considered male-gendered and associated with characteristics such as rationality and high skill requirements while work tasks such as caring for and developing other people are classified as female-gendered with skills typically considered to be inherent in the female nature. The former work tasks are often associated with higher status than the latter (6).

1 Stress Research Institute, Stockholm University, Stockholm, Sweden.

2 Institute of Environmental Medicine, Karolinska Institutet, Stockholm, Sweden.

3 Department of Public Health Sciences, Stockholm University, Stockholm, Sweden.

4 School of Health, Care, and Social Welfare, Mälardalen University, Västerås, Sweden.

Correspondence to: Anna Nyberg, Stress Research Institute, Stockholm University, 10691 Stockholm, Sweden. [E-mail: anna.nyberg@su.se] 
A mismatch between an individual's different status positions is often referred to as status inconsistency or incongruence $(7,8)$. A negative status incongruence indicates for example high educational attainment but low occupational position and a positive status incongruence the contrary. Theories on status inconsistency or incongruence were developed in the 1940s (9), and sociologists and epidemiologists have been studying the health effects of various forms of status incongruence since the 1950s (10). In the early 1970s, the extent to which congruence measure adds anything beyond that of main effects of traditional measures of socioeconomic status was disputed (11), but researchers revisited the concept again in the 1990s, some proposing a measure that summarizes several of the indicators of socioeconomic status (10). In sum, the research field is diverse, with little consensus around definitions and measures of status incongruence. Status incongruence has in later years been measured in several different ways in relation to health outcomes, and the general finding is that negative status incongruence is associated with an increased risk of adverse health outcomes (12-17).

Several theories have been developed to explain the stress that could be associated with a negative status incongruence $(8,15)$. The theory of relative deprivation (18) argues that individuals may experience stress if they, when comparing themselves with peers with corresponding educational attainment, perceive that they are less successful in terms of, for example, income or occupational position. However, not only socioeconomic position, but also cultural dimensions such as social status (eg, esteem, respect, and prestige) associated with for example different genders, ethnicities, or occupations have been suggested as important for durable inequalities $(5,19)$. Both individuals' objective socioeconomic positions and their perceptions of their social status have also been found to be associated with various mental and physical health outcomes, the latter over and above the former (20-22).

For many HSO, the skill requirements are high and the work tasks are complex. For example, teaching and nursing professions require several years of university education. These professionals may experience an inconsistency between the education they invested in and the esteem, respect or prestige that society attributes these occupations. In the present study, we investigate if employment in a HSO is associated with negative status incongruence between educational level and subjective social status over and beyond that of factors commonly measured in the status incongruence literature, such as income $(16,23,24)$ and qualification match with job demands $(15,24)$. If so, experienced lower status in relation to educational attainment could, as suggested by gender theory, be due to the fact that these femalegendered occupations are associated with lower status in society. Lower status associated with female-gendered occupations may not only have a direct effect on health but could also affect relationships between established psychosocial work factors and health outcomes (25-29). HSO include a wide variety of occupations, and the professions with higher educational requirements are more often held by men than by women (1). Furthermore, men more often than women advance to higher organizational levels, occupy managerial positions, and receive better salaries $(1,30)$ suggesting that the association between employment in a $\mathrm{HSO}$ and status incongruence may differ by gender.

The overall aim of the present study was to investigate the hypothesis that status incongruence between educational attainment and subjective social status may partly explain the excess risk of mental ill-health and sickness absence among women and men in HSO. The specific research objectives are to estimate if, among men and women (i) employment in a HSO is associated with more negative status incongruence compared with employment in other occupations, and (ii) status incongruence predicts mild-to-severe depressive symptoms and sickness absence.

\section{Methods}

\section{Study sample}

In this prospective study, we used data from two waves (2014 and 2016) of the Swedish Longitudinal Occupational Survey of Health (SLOSH), an open cohort representing an approximately nationally representative sample of the Swedish working population. Statistics Sweden has collected data every second year since 2006, and the respondents are invited to answer a selfcompletion questionnaire in two versions, one for those who work $\geq 30 \%$ of full time and another one for those who work less or not at all. More information on SLOSH can be found in the cohort profile (31). The SLOSH cohort comprised in total 20316 individuals in 2014 and 19360 individuals responded to the follow-up in 2016 (response rate 51\%). For the present study, we selected participants who answered the questionnaire for those who work $\geq 30 \%$ in 2014 and who also responded to the questionnaire for those who work $\geq 30 \%$ or to the questionnaire for those who work less or not at all in 2016 ( $\mathrm{N}=11814 ; 42 \%$ men, 58\% women). Of these, 3518 participants $(29.8 \%$ of all; $11.3 \%$ of men, $43.3 \%$ of women) were employed in a HSO. Information on sickness absence in 2016 was obtained from the Longitudinal Integration Database for Health Insurance and Labor Market Studies (LISA), which is an integrated total population register of all residents in Sweden $\geq 16$ 
years of age, provided by Statistics Sweden. Register data on sickness absence in 2016 was connected to register and self-reported data provided by SLOSH participants in 2014. The participants received written information about the study and, in accordance with Swedish regulation and practice, responding to and returning the survey indicated informed consent. The Regional Research Ethics Board in Stockholm approved the study (Dnr: 2017/236-3). The funding sources had no role in the writing of the manuscript or in the decision to submit it for publication.

\section{Variables}

$\mathrm{HSO}$, status incongruence, and all covariates were measured in 2014 and the outcome measures in 2016. The variables were used as categorical unless stated otherwise.

\section{Human service occupation}

HSO was used as a dichotomous variable, with all other occupations used as the reference category. Data on the participants' occupations were based on the Swedish Standard Classification of Occupations (SSYK 2012) and obtained from register data. We used the same definition of HSO, developed in collaboration with several Swedish authorities, as in a previous publication (2). In accordance with this definition we categorized "occupations in which contact with children, students, sick, older adults, or individuals with a vulnerable societal position is part of the daily work tasks" into HSO. Large professional groups in the present data material are teachers on all levels of the educational system and nurses and assistant nurses. Other professions included are, for example, physicians, psychologists, social workers, and priests.

\section{Status incongruence}

Status incongruence is calculated from register-based educational level and subjective social status and is a linear variable used as an outcome in the first step of our analyses and a predictor in the second step. Educational level was derived from register data and categorized into $\leq 9$ years of education, $\leq 12$ years of education, $<3$ years of university education, $\geq 3$ years of university education, and post-graduate education. Subjective social status was measured using an illustration of a ladder next to the question "Think of this ladder as representing where people stand in our society. At the top of the ladder are the people who are the best off - those with the most money, most education and the best jobs. At the bottom are the people who are worst off - those who have the least money, least education, and the worst jobs or no job. The higher up you are on this ladder, the closer you are to the people at the very top and the lower you are, the closer you are to the people at the very bottom. Mark a large $\mathrm{X}$ on the rung where you think you stand (not in between the rungs)" (32). We used a new way of assessing status incongruence, that to our best knowledge has not been applied in previous incongruence research. The variable is the standardized residual obtained in a linear regression model, adjusted for age and gender, in which subjective social status was regressed on register-based educational level. The standardized residual for each individual was saved as a new linear variable in the dataset and used to indicate status incongruence in the following analyses. The variable ranges from $-3.13-4.08$. For pedagogical reasons, we have reversed the sign so that a positive value indicates that an individual has estimated his or her social status to be lower than what the regression model predicts (indicating negative status incongruence) and a negative value that the individual has estimated his or her social status as higher than what the model predicts. We are using the whole scale of status incongruence, as a linear variable, because we are interested in estimating also if employment in a human service profession may be associated with a less positive status incongruence than employment in a non-human service profession with equivalent educational requirements. For example, a medical doctor may rate his or her social status higher than what the regression model predicts (thus being given a low value), but a lawyer or civil engineer may rate his or her status to be even higher (thus being given an even lower value).

\section{Outcome variables}

The two outcome variables were chosen to capture a breadth of possible consequences of status incongruence among working individuals. Mild-to-severe depressive symptoms was measured with the Symptom ChecklistCore Depression Scale $\left(\mathrm{SCL}-\mathrm{CD}_{6}\right)$, which is a 6-item subscale derived from the Symptom Checklist-90. The question "How much during the last week have you been troubled by..." is followed by six core symptoms of depression, namely "feeling blue/sad", "feeling no interest in things", "feeling low in energy", "feeling that everything is an effort", "worrying too much", and "blaming yourself for various things". The five response alternatives range from "not at all" to "very much" and the depression index score ranges from 0 (lowest) to 24 (highest) (33). In the present study, we used a cut-off of 10, proposed by Bech (34) to indicate mild symptoms of depression, which we have used in a previous study based on the same cohort (35). We categorized individuals with mild-to-severe symptoms of depression (values 10-24) into one group and the rest of the sample into the reference group (values 0-9). Sickness absence encompasses only absences lasting $>14$ days, for which 
all employed individuals can receive sickness benefit from the Swedish Social Insurance Agency. We used net days of sickness absence, a variable in which one day is equal either to one full day (100\%) of sickness benefit (preventive sickness benefit, rehabilitation allowance, and occupational injury allowance), two days of sickness benefit of $50 \%$ or four days of $25 \%$. We categorized the variable into either no or little sickness absence (0-30 days) and sickness absence ( $\geq 31$ days).

\section{Covariates}

Depression symptoms, measured in 2014 with the scale described above but used as a continuous variable, were adjusted for in models with mild-to-severe depressive symptoms in 2016 as the outcome. Any $(\geq 1)$ registerbased net day of sickness absence in 2014, as opposed to none, was adjusted for in models measuring register-based sickness absence $\geq 31$ days in 2016 as the outcome. Age was categorized into $\leq 34,35-44,45-54,55-64$ and $\geq 65$ years, and weekly working hours into $\leq 29,30-39,40-49$, and $\geq 50$ hours. Income was derived from register data and categorized into decentiles. Because the income variable is affected by leaves from work, sickness absences and staying home with sick children were adjusted for in models including income. Self-reported sickness absence was measured with the question "Roughly how many days in total have you been on sick leave during the past 12 months?" with the response alternatives $0,1-7,8-30$, 31-90 and $\geq 91$ days and was adjusted for in these categories. Staying home with sick children was measured with the question "How many times over the past 12 months have you stayed home caring for a sick child?" with the response alternatives "not at all", "once", "two to three times", and "four times or more" used as the categories adjusted for. Job qualification match was measured with the question "Comparing your skills and knowledge with the job you do, do you think you are"... with the following five options ..."over-qualified to a great extent", "over-qualified to some extent", "well qualified", "need some additional knowledge", "need a lot of additional knowledge".

The analyses were stratified by gender.

\section{Analytical strategy}

Differences between men and women in the distribution of study variables were calculated with Chi square test or analysis of variance. The first research question was analysed by building a gender-stratified linear regression model in two steps in which employment in a HSO, as compared with employment in any other occupation, was used as the predictor and status incongruence as the outcome. In the first step, the association was adjusted for age only and, in the second step, additionally for income, self-reported days of sickness absence, occasions staying home with sick child, working hours, and job qualification match. We conducted sensitivity analyses in which only participants working full-time were included (both $\geq 30$ and $\geq 40$ hours a week were considered). Standardized linear regression coefficients and $95 \%$ confidence intervals (CI) were reported. The second research question was analyzed, using all occupations together, with genderstratified binary logistic regression analyses in which status incongruence (2014) was the predictor and mildto-severe depressive symptoms and sickness absence $\geq 31$ days respectively (2016) the outcomes. In a first step, the associations were adjusted for age only and, in a second step, additional adjustment was made for symptoms of depression/any day of register-based sickness absence as opposed to none in 2014. We furthermore conducted analyses of mild-to-severe depressive symptoms in 2016 in which cases of mild-to-severe depressive symptoms in 2014 were excluded (men $\mathrm{N}=699$, women $\mathrm{N}=1390$ ) as well as analyses using the cut-off in the SCL-CD ${ }_{6}$ of $16 / 17$. A score $\geq 17$ has been validated against diagnostic criteria to indicate major depression (36). In the latter analyses only individuals with a score $\leq 16$ (no indication of depression) in 2014 were included. Odds ratios (OR) and 95\% CI were reported. Sensitivity analyses were conducted assessing the association between status incongruence and mild-to-severe depressive symptoms/ sickness absence $\geq 31$ days among employees in HSO only. Missing data were handled by the full information maximum likelihood. Model fit was estimated with the root mean square error of approximation (RMSEA), the Tucker-Lewis index (TLI), the comparative fit index (CFI), and the standardized root mean square residual (SRMR), with model fits suggested to be acceptable when RMSEA $\leq 0.08$, TLI $\geq 0.90$, and CFI $\geq 0.90$, and SRMR $\leq 0.08$ (37). Descriptive statistics were estimated in SPSS version 25 and the regression analyses conducted in MPLUS version 8.

\section{Results}

The distribution of the study variables is presented in table $1 \mathrm{a}$ and $\mathrm{b}$. There were statistically significant gender differences in the distribution of all study variables except occasions taking care of sick children. The linear status incongruence variable ranged from -2.99-4.08 among men and -3.13-3.66 among women.

\section{Employment in human service occupation and status incongruence}

As shown in table 2 there were, among both men and women, statistically significant associations between 
employment in a HSO, compared with employment in other occupations, and more negative status incongruence. For men, employment in a HSO was associated with an increase of 0.08 (95\% CI $0.05-0.11)$ standard deviations towards more negative status incongruence in the age-adjusted model. For women, employment in a HSO was associated with an increase of $0.12(95 \% \mathrm{CI}$ $0.10-0.15)$ standard deviations. When adjustment for the additional covariates were introduced in the second step of the model the standardized coefficient decreased to 0.04 (95\% CI 0.02-0.07) among men and 0.06 (95\% CI 0.04-0.09) among women. Similar results were found in analyses including fulltime employed only. Model fit statistics were RMSEA 0.000, TLI 1.000, CFI 1.000, and SRMR 0.000 .

\section{Status incongruence and health outcomes}

As shown in table 3, among men, each standard deviation increase towards more negative status incongruence in 2014 was associated with an OR of 1.18 (95\% CI 1.08-1.29) of mild-to-severe depressive symptoms in 2016 in the model adjusted for a linear variable of depression symptoms at baseline. The corresponding numbers were for women OR 1.17 (95\% CI 1.09-1.26). Results of analyses in which cases of mild-to-severe depressive symptoms at baseline were excluded (men $\mathrm{N}=699$, women $\mathrm{N}=1390$ ) showed OR of mild-to-severe depressive symptoms in 2016 of 1.36 (95\% CI 1.22 $1.52)$ for men and 1.32 (95\% CI 1.20-1.44) for women. In analyses using the cut-off for major depression (respondents with major depression in 2014 excluded) each standard deviation increase towards more negative status incongruence in 2014 was associated with an OR of major depression in 2016 of 1.58 (95\% CI 1.331.89 ) among men and 1.38 (95\% CI 1.20-1.58) among women. Each standard deviation increase towards more negative status incongruence was furthermore associated with an OR of 1.40 (95\% CI $1.23-1.59)$ of $\geq 31$ days of register-based sickness absence in the fully adjusted model among men and OR 1.17 (95\% CI 1.07-1.28) among women. Results were similar in models including employees in HSO only.

\section{Discussion}

The main findings of the present study were that employment in a HSO, compared with employment in other occupations, was associated with more negative status incongruence and that negative status incongruence in turn was associated with higher odds of self-reported mild-to-severe depressive symptoms and register-based sickness absence $\geq 31$ days two years later.
Table 1a. Distribution of study variables among men ( $\mathrm{N}=4981$ ), women ( $\mathrm{N}=6833$ ), and all ( $\mathrm{N}=11$ 814). Data from SLOSH 2014 and 2016.

\begin{tabular}{|c|c|c|c|c|}
\hline & $\begin{array}{c}\text { Men } \\
(\mathrm{N}=4981)\end{array}$ & $\begin{array}{l}\text { Women } \\
(\mathrm{N}=6833)\end{array}$ & $\begin{array}{c}\text { All } \\
(\mathrm{N}=11814)\end{array}$ & $\begin{array}{l}\text { P-value } \\
\text { gender }\end{array}$ \\
\hline & Mean (SD) & $\overline{\text { Mean (SD) }}$ & Mean (SD) & difference \\
\hline $\begin{array}{l}\text { Status incongruence } \\
\text { Depression symptoms } \\
2014 \text { (linear, range 0-24) }\end{array}$ & $\begin{array}{l}0.00(1.02) \\
4.56(4.54)\end{array}$ & $\begin{array}{l}0.00(0.98) \\
5.67(5.11)\end{array}$ & $\begin{array}{l}0.00(1.00) \\
5.20(4.91)\end{array}$ & $<0.001$ \\
\hline
\end{tabular}

Table 1b. Distribution of study variables among men ( $N=4981)$, women ( $\mathrm{N}=6833)$, and all ( $\mathrm{N}=11$ 814). Data from SLOSH 2014 and 2016. [SA=sickness absence.]

\begin{tabular}{|c|c|c|c|c|}
\hline & $\begin{array}{c}\text { Men } \\
(N=4981)\end{array}$ & $\begin{array}{l}\text { Women } \\
(\mathrm{N}=6833)\end{array}$ & $\begin{array}{c}\text { All } \\
(\mathrm{N}=11814)\end{array}$ & $\begin{array}{l}\text { P-value } \\
\text { gender }\end{array}$ \\
\hline & $\mathrm{N}(\%)$ & $\mathrm{N}(\%)$ & $\mathrm{N}(\%)$ & \\
\hline $\begin{array}{l}\text { Mild-to-severe depressive } \\
\text { symptoms } 2016 \text { (binary) }\end{array}$ & $669(13.4)$ & $1281(18.7)$ & 1950 (16.5) & $<0.001$ \\
\hline$\leq 1$ net day(s) of SA 2014 & $354(7.1)$ & $848(12.4)$ & $1202(10.2)$ & $<0.001$ \\
\hline$>31$ net days of SA 2016 & $211(4.2)$ & $547(8.0)$ & $758(6.4)$ & $<0.001$ \\
\hline Human service occupation & $562(11.3)$ & 2956 (43.3) & $3518(29.8)$ & $<0.001$ \\
\hline $\begin{array}{l}\text { Age (years) } \\
\leq 34 \\
35-44 \\
45-54 \\
55-64 \\
\geq 65\end{array}$ & $\begin{array}{r}291(5.8) \\
862(17.3) \\
1465(29.4) \\
1978(39.7) \\
385(7.7)\end{array}$ & $\begin{array}{r}471(6.9) \\
1198(17.5) \\
2206(32.3) \\
2628(38.5) \\
330(4.8)\end{array}$ & $\begin{array}{r}762(6.4) \\
2060(17.4) \\
3671(31.1) \\
4606(39.0) \\
715(6.1)\end{array}$ & $<0.001$ \\
\hline $\begin{array}{l}\text { Education (years) } \\
\leq 9 \\
\leq 12 \\
<3 \text { university education } \\
\geq 3 \text { university education } \\
\text { Post-graduate education }\end{array}$ & $\begin{array}{r}468(9.4) \\
2238(44.9) \\
493(9.9) \\
1664(33.4) \\
115(2.3)\end{array}$ & $\begin{array}{r}304(4.4) \\
2576(37.7) \\
364(5.3) \\
3485(51.0) \\
103(1.5)\end{array}$ & $\begin{array}{r}772(6.5) \\
4814(40.7) \\
857(7.3) \\
5149(43.6) \\
218(1.8)\end{array}$ & $<0.001$ \\
\hline $\begin{array}{l}\text { Income (SEK) } \\
0-230860 \\
230900-273036 \\
273038-299228 \\
299241-323136 \\
323138-349167 \\
349185-378045 \\
378059-416782 \\
416820-472732 \\
472769-584759 \\
584878-2804620\end{array}$ & $\begin{array}{r}293(5.9) \\
252(5.1) \\
320(6.4) \\
396(8.0) \\
444(8.9) \\
516(10.4) \\
610(12.2) \\
635(12.7) \\
707(14.2) \\
808(16.2)\end{array}$ & $\begin{array}{r}894(13.1) \\
929(13.6) \\
862(12.6) \\
785(11.5) \\
737(10.8) \\
666(9.7) \\
571(8.4) \\
547(8.0) \\
474(6.9) \\
368(5.4)\end{array}$ & $\begin{array}{l}1187(10) \\
1181(10) \\
1182(10) \\
1181(10) \\
1181(10) \\
1182(10) \\
1181(10) \\
1182(10) \\
1181(10) \\
1176(10)\end{array}$ & $<0.001$ \\
\hline $\begin{array}{l}\text { Subjective social status } \\
1 \\
2 \\
3 \\
4 \\
5 \\
6 \\
7 \\
8 \\
9 \\
10\end{array}$ & $\begin{array}{r}5(0.1) \\
38(0.8) \\
131(2.6) \\
336(6.7) \\
481(9.7) \\
979(19.7) \\
1549(31.1) \\
1081(21.7) \\
261(5.2) \\
52(1.0)\end{array}$ & $\begin{array}{r}7(0.1) \\
151(0.7) \\
168(2.5) \\
432(6.3) \\
788(11.5) \\
1554(22.7) \\
2128(31.1) \\
1260(18.4) \\
271(4.0) \\
38(0.6)\end{array}$ & $\begin{array}{r}12(0.1) \\
89(0.8) \\
299(2.5) \\
768(6.5) \\
1269(10.7) \\
2533(21.4) \\
3677(31.1) \\
2341(19.8) \\
532(4.5) \\
90(0.8)\end{array}$ & $<0.001$ \\
\hline $\begin{array}{l}\text { Working hours per week } \\
\leq 29 \\
30-39 \\
40-49 \\
\geq 50\end{array}$ & $\begin{array}{r}445(8.9) \\
821(16.5) \\
3045(61.1) \\
627(12.6)\end{array}$ & $\begin{array}{r}1107(16.2) \\
2025(29.6) \\
3236(47.4) \\
407(6.0)\end{array}$ & $\begin{array}{r}1552(13.1) \\
2846(24.1) \\
6281(53.2) \\
1034(8.8)\end{array}$ & $<0.001$ \\
\hline $\begin{array}{l}\text { Greatly over-qualified } \\
\text { Somewhat over-qualified } \\
\text { Well qualified } \\
\text { Need more knowledge } \\
\text { Need a lot more knowledge }\end{array}$ & $\begin{array}{r}144(2.9) \\
1030(20.7) \\
3028(60.8) \\
690(13.9) \\
51(1.0)\end{array}$ & $\begin{array}{r}145(2.1) \\
1174(17.2) \\
4279(62.6) \\
1138(16.7) \\
64(0.9)\end{array}$ & $\begin{array}{r}289(2.4) \\
2204(18.7) \\
7307(61.9) \\
1828(15.5) \\
115(1.0)\end{array}$ & \\
\hline $\begin{array}{l}\text { Self-reported SA (days over } \\
\text { past } 12 \text { months) }\end{array}$ & & & & $<0.001$ \\
\hline $\begin{array}{l}0 \\
1-7 \\
8-30 \\
31-90 \\
\geq 91\end{array}$ & $\begin{array}{r}2651(53.2) \\
1615(32.4) \\
515(10.3) \\
100(2.0) \\
60(1.2)\end{array}$ & $\begin{array}{r}2617(38.3) \\
2664(39.0) \\
1033(15.1) \\
282(4.1) \\
193(2.8)\end{array}$ & $\begin{array}{r}5268(44.6) \\
4279(36.2) \\
1548(13.1) \\
382(3.2) \\
253(2.1)\end{array}$ & \\
\hline $\begin{array}{l}\text { Home with sick child (times } \\
\text { over past } 12 \text { months) }\end{array}$ & & & & 0.247 \\
\hline $\begin{array}{l}0 \\
1\end{array}$ & $\begin{array}{r}4117(82.7) \\
214(4.3)\end{array}$ & $\begin{array}{r}5556(81.3) \\
295(4.3)\end{array}$ & $\begin{array}{r}9673(81.9) \\
509(4.3)\end{array}$ & \\
\hline $2-3$ & $312(6.3)$ & $482(7.1)$ & $794(6.7)$ & \\
\hline$\geq 4$ & $230(4.6)$ & $341(5.0)$ & $571(4.8)$ & \\
\hline
\end{tabular}


Table 2. Standardized linear regression coefficients and 95\% confidence intervals (CI) for more negative status incongruence among employees in human service occupations (HSO) compared with employees in all other occupations on the Swedish labor market, and covariates. All predictor variables are categorical, with the reference category not shown. Data from SLOSH 2014 ( $N=11814)$. Model fit: RMSEA 0.000, TLI 1.000, CFI 1.000 , and SRMR 0.000

\begin{tabular}{|c|c|c|c|c|c|c|c|c|}
\hline & \multicolumn{4}{|c|}{ Men $(\mathrm{N}=4981)$} & \multicolumn{4}{|c|}{ Women $(\mathrm{N}=6833)$} \\
\hline & \multicolumn{2}{|c|}{ Model $1^{\mathrm{a}}$} & \multicolumn{2}{|c|}{ Model $2^{b}$} & \multicolumn{2}{|c|}{ Model $1^{\text {a }}$} & \multicolumn{2}{|c|}{ Model $2^{b}$} \\
\hline & Coefficient & $95 \% \mathrm{Cl}$ & Coefficient & $95 \% \mathrm{Cl}$ & Coefficient & $95 \% \mathrm{Cl}$ & Coefficient & $95 \% \mathrm{Cl}$ \\
\hline HSO & 0.08 & $0.05-0.11$ & 0.04 & $0.02-0.07$ & 0.12 & $0.10-0.15$ & 0.06 & $0.04-0.09$ \\
\hline \multicolumn{9}{|l|}{ Age } \\
\hline $35-44$ & -0.04 & $-0.09-0.01$ & 0.04 & $-0.01-0.09$ & -0.07 & $-0.11--0.03$ & -0.01 & $-0.05-0.03$ \\
\hline $45-54$ & -0.07 & $-0.13--0.01$ & 0.04 & $-0.02-0.09$ & -0.06 & $-0.11--0.01$ & 0.02 & $-0.02-0.07$ \\
\hline $55-64$ & -0.06 & $-0.12-0.00$ & 0.03 & $-0.03-0.09$ & -0.03 & $-0.08-0.02$ & 0.05 & $0.00-0.10$ \\
\hline$\geq 65$ & -0.07 & $-0.11--0.03$ & -0.02 & $-0.06-0.02$ & -0.02 & $-0.05-0.01$ & 0.03 & $0.00-0.06$ \\
\hline \multicolumn{9}{|l|}{ Income (decentiles) } \\
\hline $2^{\text {nd }}$ & & & 0.03 & $-0.00-0.07$ & & & -0.00 & $-0.03-0.03$ \\
\hline $3^{\text {rd }}$ & & & 0.01 & $-0.03-0.04$ & & & -0.05 & $-0.09--0.02$ \\
\hline $4^{\text {th }}$ & & & -0.01 & $-0.05-0.03$ & & & -0.07 & $-0.10--0.04$ \\
\hline $5^{\text {th }}$ & & & -0.03 & $-0.07-0.01$ & & & -0.08 & $-0.11--0.05$ \\
\hline $6^{\text {th }}$ & & & -0.04 & $-0.08-0.00$ & & & -0.06 & $-0.09--0.03$ \\
\hline $7^{\text {th }}$ & & & -0.11 & $-0.16--0.07$ & & & -0.11 & $-0.13--0.08$ \\
\hline $8^{\text {th }}$ & & & -0.16 & $-0.21--0.12$ & & & -0.14 & $-0.17--0.11$ \\
\hline $9^{\text {th }}$ & & & -0.23 & $-0.28--0.19$ & & & -0.18 & $-0.20--0.15$ \\
\hline $10^{\text {th }}$ & & & -0.33 & $-0.38--0.29$ & & & -0.21 & $-0.24--0.18$ \\
\hline \multicolumn{9}{|l|}{ Childcare (occasions) } \\
\hline 1 & & & 0.00 & $-0.02-0.03$ & & & 0.01 & $-0.01-0.03$ \\
\hline $2-3$ & & & -0.02 & $-0.05-0.01$ & & & -0.00 & $-0.03-0.02$ \\
\hline$\geq 4$ & & & -0.01 & $-0.04-0.02$ & & & 0.00 & $-0.02-0.03$ \\
\hline \multicolumn{9}{|l|}{ Sickleave (days) } \\
\hline $1-7$ & & & 0.06 & $0.03-0.08$ & & & 0.03 & $0.00-0.05$ \\
\hline 8-30 & & & 0.10 & $0.08-0.13$ & & & 0.08 & $0.05-0.10$ \\
\hline $31-90$ & & & 0.03 & $0.01-0.06$ & & & 0.03 & $0.01-0.06$ \\
\hline$\geq 91$ & & & 0.02 & $-0.01-0.04$ & & & 0.05 & $0.03-0.07$ \\
\hline \multicolumn{9}{|l|}{ Weekly work hours } \\
\hline $30-39$ & & & -0.05 & $-0.09--0.01$ & & & -0.02 & $-0.06-0.01$ \\
\hline $40-49$ & & & -0.07 & $-0.11--0.02$ & & & 0.00 & $-0.03-0.04$ \\
\hline$\geq 50$ & & & -0.09 & $-0.12--0.05$ & & & -0.01 & $-0.03-0.02$ \\
\hline \multicolumn{9}{|l|}{ Qualification } \\
\hline Somewhat over-qualified & & & -0.04 & $-0.10-0.02$ & & & -0.06 & $-0.11-0.00$ \\
\hline Well qualified & & & -0.10 & $-0.17--0.03$ & & & -0.11 & $-0.18--0.04$ \\
\hline Need more knowledge & & & -0.03 & $-0.09-0.02$ & & & -0.04 & $-0.10-0.02$ \\
\hline Need a lot more knowledge & & & -0.01 & $-0.02-0.04$ & & & 0.01 & $-0.01-0.04$ \\
\hline
\end{tabular}

a Model 1: Adjusted for age

${ }^{\mathrm{b}}$ Model 2: Model $1+$ income, childcare, sick leave, workhours, and job qualification match.

Table 3. Odds ratios (OR) and 95\% confidence interval (Cl) for mild-to-severe depressive symptoms and $\geq 31$ days of register-based sickness absence (SA) in 2016 for each standard deviation increase in status incongruence in 2014 in models adjusted for age, depression symptoms and any registerbased day of SA respectively in 2014. Data from SLOSH (N=11 814). Model fit: RMSEA 0.000, TLI 1.000, CFI 1.000, and SRMR 0.000.

\begin{tabular}{|c|c|c|c|c|c|c|c|c|}
\hline & \multicolumn{4}{|c|}{ Men $(\mathrm{N}=4981)$} & \multicolumn{4}{|c|}{ Women ( $\mathrm{N}=6833$ ) } \\
\hline & \multicolumn{4}{|c|}{$\begin{array}{l}\text { Mild-to-severe depressive symptoms } 2016 \\
\qquad(\mathrm{~N}=669,13.4 \%)\end{array}$} & \multicolumn{4}{|c|}{$\begin{array}{l}\text { Mild-to-severe depressive symptoms } 2016 \\
\qquad(\mathrm{~N}=1281,18.7 \%)\end{array}$} \\
\hline & \multicolumn{2}{|c|}{ Model $1^{\mathrm{a}}$} & \multicolumn{2}{|c|}{ Model $2^{b}$} & \multicolumn{2}{|c|}{ Model $1^{\text {a }}$} & \multicolumn{2}{|c|}{ Model $2^{b}$} \\
\hline & OR & $95 \% \mathrm{Cl}$ & $\mathrm{OR}$ & $95 \% \mathrm{Cl}$ & OR & $95 \% \mathrm{Cl}$ & OR & $95 \% \mathrm{Cl}$ \\
\hline Status incongruence 2014 & 1.52 & $1.41-1.64$ & 1.18 & $1.08-1.29$ & 1.49 & $1.40-1.59$ & 1.17 & $1.09-1.26$ \\
\hline Depression symptoms 2014 & & & 1.30 & $1.27-1.32$ & & & 1.22 & $1.21-1.24$ \\
\hline
\end{tabular}

$\geq 31$ SA days $2016(\mathrm{~N}=211,4.2 \%)$

$\geq 31$ SA days $2016(\mathrm{~N}=547,8.0 \%)$

\begin{tabular}{|c|c|c|c|c|c|c|c|c|}
\hline & & \\
\hline & \multicolumn{2}{|c|}{ Model $1^{\mathrm{a}}$} & \multicolumn{2}{|c|}{ Model $2^{\text {b }}$} & \multicolumn{2}{|c|}{ Model $1^{\mathrm{a}}$} & \multicolumn{2}{|c|}{ Model $2^{b}$} \\
\hline & $\mathrm{OR}$ & $95 \% \mathrm{Cl}$ & $\mathrm{OR}$ & $95 \% \mathrm{Cl}$ & OR & $95 \% \mathrm{Cl}$ & OR & $95 \% \mathrm{Cl}$ \\
\hline Status incongruence 2014 & 1.46 & $1.29-1.66$ & 1.40 & $1.23-1.59$ & 1.21 & $1.11-1.32$ & 1.17 & $1.07-1.28$ \\
\hline$S A \geq 1$ day 2014 & & & 1.97 & $1.66-2.34$ & & & 1.84 & $1.67-2.04$ \\
\hline
\end{tabular}

aodel 1: Adjusted for age.

${ }^{\mathrm{b}}$ Model 2: Model 1 + depression symptoms 2014 (linear variable)/register-based SA $\geq 1$ day 2014. 
Employment in human service occupation and status incongruence

Women and men in HSO rate their social status somewhat lower than employees in other occupations with equivalent educational backgrounds on the Swedish labor market. The effect size is rather small, but on the other hand it affects a large part of the working population. Income was strongly associated with status incongruence. In the theory of relative deprivation, experienced negative status incongruence has been discussed to be related to a perception of distributive injustice and to a discrepancy between investments (in terms of education, for example) and rewards (in terms of financial situation, for example) (18). HSO employees who are underpaid in relation to other professions with corresponding educational requirements (38) may, in accordance with this theory, experience a discrepancy between investments, in terms of their educational background and rewards, in terms of their salaries. However, the association between employment in a HSO and negative status incongruence could not fully be explained only by income or the other included covariates. Subjective social status is a measure that theoretically goes beyond that of socioeconomic position in terms of access to power and resources and indicates a sense of value in the society to which one belongs (5). Based on findings from the Whitehall study in Britain, Singh-Manoux et al (22) argue that subjective social status appears to more fully reflect the total sociocultural circumstances of the individual than other broad objective measures of socioeconomic position. In line with this argument, our results suggest that HSO employees in Sweden may find the work they do is not valued by the society to which they belong to the same extent as employees with equivalent educational backgrounds in other occupations. This could be due to that women's work, according to theory $(4,5)$, is generally less valued than men's work by society at large, and could also be associated with the continuous cuts in resources to the human service sector since the middle of the 1990s with deteriorating working conditions as a consequence (39). To what extent negative status incongruence as measured in the present study affects the association between psychosocial work stressors and health outcomes (25-29) is a research question that should be explored further. For example, high job demands may be more strongly associated with negative mental health outcomes depending on the social status of the job demands per se, whether oriented towards caring for others (lower status) or towards data or technical skills (higher status).

\section{The implication of status incongruence for health outcomes}

The odds of mild-to-severe depressive symptoms decreased markedly in both genders with the introduc- tion of adjustment for depression symptoms at baseline whereas sickness absence $\geq 31$ days remained relatively unchanged with the introduction of baseline adjustment for sickness absence $\geq 1$ day. This may not be surprising since both depression symptoms and subjective social status are self-reported and may be interrelated, whereas sickness absence is register-based. The adjusted results may be considered as conservative since a reverse association between the variables is also plausible, ie, that depression symptoms and sickness absence affect experienced social status negatively over time. The effect of status incongruence on mild-to-severe depressive symptoms and depression was evident also after excluding cases of the respective outcome at baseline. The present study supports the results of several previous ones of various more traditional measures of status incongruence, reporting associations with outcomes such as mental well-being (17), depression symptoms $(13,16)$, poor self-rated health $(15)$, and risk of cardiovascular disease (14). In the present study, the odds of sickness absence $\geq 31$ days for each standard deviation increase in negative status incongruence is particularly high among men.

\section{Strengths and limitations}

Besides the strength of the prospective design and high-quality data used in the present study, it gives a novel contribution with its focus on social status associated with typically female gendered occupations in relation to educational requirements and a measure of social status that may more adequately capture an individual's total sociocultural life circumstances. This may be particularly relevant for studies of value or esteem associated with differently gendered occupations. However, the measure of status incongruence used in the study has not been used before. Although it is based on educational level derived from register data and a validated scale of subjective social status, future research may prove the usefulness of this scale for other research questions. There is a selective drop out from the SLOSH cohort; more women, well-educated, Swedish-born, and employees in the public sector remain in the cohort. Although gender, education and, to some extent, sector (through HSO) is taken into consideration in the analyses of the present study, the results cannot be generalized to the Swedish working population as a whole. The measure of sickness absence is non-specific and no conclusions can be drawn regarding specific diagnoses. The measure of mild-to-severe depressive symptoms is furthermore self-reported. However, the longer version of the scale, the SCL depression scale, has been validated against clinical diagnostic interviews and found to be robust (36). 


\section{Concluding remarks}

Status incongruence is somewhat higher among HSO than other occupations and is associated with increased odds of depressive symptoms and register-based sickness absence. The possible moderating role of status incongruence in the association between established work stressors and negative health outcomes should be investigated in future studies. Arenas to target with interventions may be the gender-segregated labor market, the wage distribution in HSO, and more generally social status associated with gender.

\section{Funding}

This work was supported by AFA Insurance [grant number 150474]. Data collection was supported by the Swedish Research Council for Health, Working Life and Welfare (FORTE) through the Stockholm Stress Center (Grant 2009-1758) and the Swedish Research Council (VR; Grant 2013-0164 and 2013-01646). The funding sources had no role in the writing of the manuscript or the decision to submit it for publication.

\section{Declaration of interests}

The authors declare no conflicts of interest.

\section{References}

1. Swedish Social Insurance Agency. Sick leave at the Swedish labour market. Sick leave longer than 14 days and termination of sick leave within 180 days by indutry and occupation. Stockholm; 2018.

2. Aronsson V, Toivanen S, Leineweber C, Nyberg A. Can a poor psychosocial work environment and insufficient organizational resources explain the higher risk of ill-health and sickness absence in human service occupations? Evidence from a Swedish national cohort. Scand J Public Health 2019 May;47(3):310-7. https://doi. org/10.1177/1403494818812638.

3. Ward-Griffin C, Brown JB, St-Amant O, Sutherland N, MartinMatthews A, Keefe J et al. Nurses negotiating professionalfamilial care boundaries: striving for balance within double duty caregiving. J Fam Nurs 2015 Feb;21(1):57-85. https:// doi.org/10.1177/1074840714562645.

4. Acker J. Hierarchies, jobs, bodies: a theory of gendered organizations. Gend Soc 1990;4(2):139-58. https://doi. org/10.1177/089124390004002002.

5. Ridgeway CL. Why status matters for inequality. Am Sociol Rev 2014;79(1):1-16. https://doi.org/10.1177/0003122413515997.

6. Kohn M, Schooler C. Work and personality: An inquiry into the impact of social stratification. Ablex; 1986. p. 1079-80.
7. Vernon SW, Buffler PA. The status of status inconsistency. Epidemiol Rev 1988;10(1):65-86. https://doi.org/10.1093/ oxfordjournals.epirev.a036029.

8. Garcy AM. Educational mismatch and mortality among native-born workers in Sweden. A 19-year longitudinal study of 2.5 million over-educated, matched and undereducated individuals, 1990-2008. Sociol Health Illn 2015 Nov;37(8):1314-36. https://doi.org/10.1111/14679566.12312 .

9. Hughes EC. Dilemmas and contradictions of status. Am J Sociol 1945;50:353-9. https://doi.org/10.1086/219652.

10. Dressler WW. Social or status incongruence. In: Anderson NB, editor. The encyclopedia of health and behavior. Thousand Oaks, CA: Sage Publications; 2004. p. 764-7.

11. Whitt HP. Status inconsistency: A body of negative evidence or a statistical artifact? Soc Forces 1983;62(1):201-33. https://doi.org/10.2307/2578356.

12. Faresjö T, Svärdsudd K, Tibblin G. The concept of status incongruence revisited: a 22-year follow-up of mortality for middle-aged men. Scand J Soc Med 1997 Mar;25(1):28-32. https://doi.org/10.1177/140349489702500107.

13. Bracke P, Pattyn E, von dem Knesebeck O. Overeducation and depressive symptoms: diminishing mental health returns to education. Sociol Health Illn 2013 Nov;35(8):1242-59. https://doi.org/10.1111/1467-9566.12039.

14. Braig S, Peter R, Nagel G, Hermann S, Rohrmann S, Linseisen J. The impact of social status inconsistency on cardiovascular risk factors, myocardial infarction and stroke in the EPIC-Heidelberg cohort. BMC Public Health 2011 Feb;11:104. https://doi.org/10.1186/1471-2458-11-104.

15. Dunlavy AC, Garcy AM, Rostila M. Educational mismatch and health status among foreign-born workers in Sweden. Soc Sci Med 2016 Apr;154:36-44. https://doi.org/10.1016/j. socscimed.2016.02.018.

16. Friedland DS, Price RH. Underemployment: consequences for the health and well-being of workers. Am J Community Psychol 2003 Sep;32(1-2):33-45. https://doi. org/10.1023/A:1025638705649.

17. Lundberg J, Kristenson M, Starrin B. Status incongruence revisited: associations with shame and mental wellbeing. Sociol Health Illn 2009 May;31(4):478-93. https://doi. org/10.1111/j.1467-9566.2008.01148.x.

18. Wegener B. Relative deprivation and social mobility: structural constraints on distributive justice judgments. Eur Sociol Rev 1991;7(1):3-18. https://doi.org/10.1093/ oxfordjournals.esr.a036575.

19. Weber M. Economy and society. Roth G, Wittich C, editors. New York: Bedminster; (1918) 1968.

20. Miething A. The relevance of objective and subjective social position for self-rated health: A combined approach for the Swedish context. Soc Indic Res 2013;111(1):161-73. https:// doi.org/10.1007/s11205-011-9988-1.

21. Singh-Manoux A, Marmot MG, Adler NE. Does subjective social status predict health and change in health status better than objective status? Psychosom Med 2005 Nov-Dec;67(6):855-61. https://doi.org/10.1097/01. 
psy.0000188434.52941.a0

22. Singh-Manoux A, Martikainen P, Ferrie J, Zins M, Marmot M, Goldberg M. What does self rated health measure? Results from the British Whitehall II and French Gazel cohort studies. J Epidemiol Community Health 2006 Apr;60(4):364-72. https://doi.org/10.1136/ jech.2005.039883.

23. Zhang X. Status Inconsistency Revisited: An Improved Statistical Model. Eur Sociol Rev 2008;24(2):155-68. https://doi.org/10.1093/esr/jcm048.

24. Korpi T, Tåhlin M. Educational mismatch, wages, and wage grouwth: overeducation in Sweden, 1994-2000. Labour Econ 2009;16:183-93. https://doi.org/10.1016/j. labeco.2008.08.004.

25. Theorell T, Hammarström A, Aronsson G, Träskman Bendz L, Grape T, Hogstedt C et al. A systematic review including meta-analysis of work environment and depressive symptoms. BMC Public Health 2015 Aug;15:738. https:// doi.org/10.1186/s12889-015-1954-4.

26. Aronsson G, Theorell T, Grape T, Hammarström A, Hogstedt C, Marteinsdottir I et al. A systematic review including meta-analysis of work environment and burnout symptoms. BMC Public Health 2017 Mar;17(1):264. https:// doi.org/10.1186/s12889-017-4153-7.

27. Linton SJ, Kecklund G, Franklin KA, Leissner LC, Sivertsen $\mathrm{B}$, Lindberg $\mathrm{E}$ et al. The effect of the work environment on future sleep disturbances: a systematic review. Sleep Med Rev 2015 Oct;23:10-9. https://doi.org/10.1016/j. smrv.2014.10.010.

28. Van Laethem M, Beckers DG, Kompier MA, Dijksterhuis A, Geurts SA. Psychosocial work characteristics and sleep quality: a systematic review of longitudinal and intervention research. Scand J Work Environ Health 2013 Nov;39(6):535-49. https://doi.org/10.5271/sjweh.3376.

29. Stansfeld S, Candy B. Psychosocial work environment and mental health--a meta-analytic review. Scand J Work Environ Health 2006 Dec;32(6):443-62. https://doi. org/10.5271/sjweh.1050.

30. Nyberg A, Magnusson Hanson LL, Leineweber C, Johansson G. Do Predictors of Career Success Differ between Swedish Women and Men? Data from the Swedish Longitudinal Occupational Survey of Health (SLOSH). PLoS One 2015 Oct;10(10):e0140516. https://doi.org/10.1371/journal. pone. 0140516 .
31. Magnusson Hanson L, Leineweber C, Persson V, Hyde M, Theorell T, Westerlund H. Cohort Profile: The Swedish Longitudinal Occupational Survey of Health (SLOSH). Int J Epidemiol 2018. [Epub ahead of print].

32. Singh-Manoux A, Adler NE, Marmot MG. Subjective social status: its determinants and its association with measures of ill-health in the Whitehall II study. Soc Sci Med 2003 Mar;56(6):1321-33. https://doi.org/10.1016/S02779536(02)00131-4.

33. Magnusson Hanson LL, Westerlund H, Leineweber C, Rugulies R, Osika W, Theorell $\mathrm{T}$ et al. The Symptom Checklist-core depression (SCL-CD6) scale: psychometric properties of a brief six item scale for the assessment of depression. Scand J Public Health 2014 Feb;42(1):82-8. https://doi.org/10.1177/1403494813500591.

34. Bech P. Klinisk Psykometri. Copenhagen, Denmark: Munksgard; 2011.

35. Nyberg A, Magnusson Hanson LL, Leineweber C, Hammarström A, Theorell T. Occupational gender composition and mild-to-severe depression in a Swedish cohort: the impact of psychosocial work factors. Scand J Public Health 2018 May;46(3):425-32. https://doi. org/10.1177/1403494817745736.

36. Lundin A, Hallgren M, Forsell Y. The validity of the symptom checklist depression and anxiety subscales: A general population study in Sweden. J Affect Disord 2015 Sep;183:247-52. https://doi.org/10.1016/j.jad.2015.05.024.

37. Little TD. Longitudinal Structural Equation Modeling. New York: Guilford Press; 2013.

38. SOU. Hela lönen, hela tiden. Utmaningar för ett jämställt arbetsliv. [The whole salary, all the time. Challengies for a gender equal working life] SOU 2015:50. Stockholm: Statens offentliga utredningar; 2015.

39. Rasmussen B. Between endless needs and limited resosurces: the gendered construction of a greedy organization. Gend Work Organ 2004;11(5):506-25. https:// doi.org/10.1111/j.1468-0432.2004.00245.x.

Received for publication: 28 May 2019 